\title{
Anxiety/Depression And Academic Achievement In Adolescents In Prishtina
}

\section{Nerxhivane Krasniqi}

Doct. European University of Tirana

Doi:10.5901/jesr.2014.v4n2p375

\author{
nexha61@gmail.com, Tel. +37744193961
}

\section{Abstract}

Numerous empirical studies suggest that psychological difficulties of children and adolescents are negatively correlated with academic achievement. The main purpose of the study is the recognition level of emotional problems-anxiety and depression to an adoleshent school sample in Prishtina and their relation with academic achievement. A sample of the school population (219 children aged from 10 years to 18),38.8\% boys and 61.2\% girls have completed instruments:Revised Children Manifest Anxiety Scale(RCMAS) and Depression Self-Rating Scale for children. $15 \%$ of cases have resulted in anxiety and $22.1 \%$ with depression. Results showed that anxiety and depression have no significant correlation with success at school while having significant positive correlation between them $(r=.56, p<.00)$ with great effect size. Nonsignificaly students with depression had a poor success and those with anxiety had better success. Also the results showed statistically significant gender differences in the level of anxiety and depression. Women have more anxiety $(r=.24, p<.00)$ and depression $(r=.20, p<.01)$; in both cases the effect size is small. The multiple standard regresion analysis of academic achievement as the dependent variable and gender, age, anxiety and depression as independent variables resulted in a significant statistical model $(R 2=.216, F(5,131)=6.598$, $p<.00)$. Hovewer, the model describes only $21 \%$ of shown success variance, significant unique contribution have given gender $(\beta=.17, p<.04)$, residence $(\beta=.24, p<.00)$,age $(\beta=-.19, p<.02)$ depression $(\beta=-.24, p<.01)$ and anxiety $(\beta=.20, p<.03)$. These results have important implications in the context of addressing anxiety and depression with the goal of improving academic achievement.

Keywords:academic achievement , anxiety, depression,students, Prishtina.

\section{Background}

\subsection{Anxiety, depression, academic success}

Experiencing emotional states such as anxiety and depression is a universal phenomenon (Spielberger, 2006). Anxiety is one of the most common psychological disorders in school-aged children and adolescents worldwide (Costello, Mustillo, Erkanli,Keeler \& Angold, 2003). The prevalence rates range from $4.0 \%$ to $25.0 \%$, with an average rateof $8.0 \%$ (Bernstein \& Borchardt, 1991; Boyd,Kostanski, Gullone, Ollendick \& Shek, 2000). Anxiety is associated with substantial negative effects on children's social, emotional and academic success (Essau, Conradt \& Petermann, 2000) and with negative sequelae: poorer academic performance and higher rates of school drop out (lalongo, Edelsohn, Werthamer-Larsson, Crocket \& Kellam ,1994; Ialongo, Edelsohn, Werthamer-Larsson, Crocket \& Kellam ,1995; Kusche, Cook, Greenberg , 1993).

The depressive syndrome in young people has been estimated at 10 to $30 \%$ by some researchers (Hammen \& Rudolph, 2003). Edwards and Holden (2001) found that among college students seeking counseling services, anxiety and depression were ranked first and third as presenting problems.

Performance in academic life demands all aspects of well-being, those that include physical, social, emotional, spiritual, and psychological well-being (Crystal, Chen, Fuligni, Stevenson, Hsu, Ko, Kitamura, \& Kimura, 1994).

\subsection{Literature review: anxiety, depresion and academic success}

Numerous empirical studies suggest that children's psychlogical difficulties are negatively correlated with academic achievement.Previously is been known that anxiety plays significant role in student's learnings and academic 
performance (Tobias, 1979). According to Owens (2012) :" a finding that schoolchildren and adolescents experiencing high levels of anxiety or depression are at risk for poor academic performance (Hembree, 1988) has been replicated in many countries including South Africa, Finland, Australia, the UK, Germany, the USA, and others".

The majority of the research literature in this area has tended to focus on anxiety rather than depression, a fact which is reflected in the extant meta-anlayses on anxiety and test anxiety (Ergene, 2003; Hembree, 1988; Ma, 1999). The researches show that psychological problems like anxiety and depression affect academic achievement inversely; especially the high level of anxiety has more damaging effect on academic achievement and can lead to lower academic performance and poorer working mFkrasniqiemory function; because school tasks that involve more working memory are greatly affected (Owens et al., 2012). In same time this effect is due to poor school attendance and the negative behavior (Hughes, Lourea-Waddell \& Kendall, 2008). Similarly, in research carried out by Von Ameringen et al. (2003), results suggest that children and adolescents with anxiety problems suffer greater risk of failing academically, of dropping out of school, and of not aspiring to higher education, when compared to the normal population. In this line, results from Mazzone et al. (2007) reveal a statistically significant association between high level self-reported anxiety and poor academic performance. Thus, children with high levels of anxiety were more likely to have school grades in the failure range, as compared to children with low scores in anxiety.

lalongo et al. (1995) followed first grade children for $4 \frac{1}{2} 2$ years and found that the children who were in the top third of self-reported anxiety symptoms were 10 times more likely to be in the bottom third of achievement in the fifth grade. Moreover, research findings suggest children and adolescents with anxiety problems are at increased risk of underachieving in school, dropping out of school, and/or not pursuing higher education compared to the general population (Kessler, Foster, Saunders \& Stang, 1995; Von Ameringen, Mancini \& Farvolden, 2003) .

Regarding depression in children and adolescents the results of the studies showed that there was an inverse relationship between academic achievement and depression. Moreover, several researchers have linked depressive disorders or symptoms to underachievement (e.g., PuigAntich et al., 1993). Adolescents with depression are at increased risk for impairment in school and educational attainment (Asarnow, Jaycox, Duan, LaBorde, et al., 2005).This notion was then supported by Zaid, Chan, and Ho (2007) in the study on emotional disorders among medical students in one of the Malaysian private colleges found that students who experienced depression had a lower academic performance.

Eisenberg, Golberstein, \& Hunt (2009) stated that detailed descriptive analysis of association between mental health and academic outcomes in college showed depression as a significant predictor of lower GPA (Grade Point Average) and co-occurring anxiety and depression have an additional negative association with GPA. Students who experience mild or moderate symptoms of depression or anxiety also demonstrate more academic difficulties and lower GPA then non-depressed students (Locke, 2009; Deroma, Leach, and Leverett, 2009). Certainly, clinical depression is often associated with both an inability to concentrate and intrusive ruminative thoughts (Nolen-Hoeksema, 2000) which are likely to reduce available cognitive resources. Many clinical descriptive reports suggested that depression may be a contributing factor to poor academic performance (Fine \& Carlson, 1994). It is noteworthy that other researchers have found no connections between internalizing symptoms and poor academic performance (e.g., Reinherz et al., 1993).

\section{Aims}

In this study, it is aimed to estimate the levels of depresion and anxiety to a sample of adoloscents in Prishtina and their correlation with academic achievement.At the same time it will be analysed socio-demografic factors such as age, gender and residence and their correlation anxiety, depression and academic achievement in adolescents.

The scope of this research is to answer the following questions:

1) Do the anxiety levels of students show a significant difference according to their age, gender and residence? 
2) Do the depression levels of students show a significant difference according to their age, gender and residence?

3) Do the academic success levels of students based on GPA show a significant difference according to their age, gender and residence?

4) Do the academic success levels of students based on GPA show a significant difference according to their presence of anxiety?

5) Do the academic success levels of students based on GPA show a significant difference according to their presence of depression?

6) Do the levels of anxiety and depresion can predict academic success levels of students based on GPA ?

\section{Method}

The population of this descriptive study, carried out to identify depression, anxiety and the academic success levels of students of the primary and secondary schools in Prishtina kapital city of Kosovo. The data were obtained by using The Revised Children Manifest Anxiety Scale (RCMAS) and The Depression Self-Rating Scale for Children that were applied to students in the school, between 15 and 30 January in 2014. In terms of the accessibility the study group consists of 219 students randomly selected, aged 10-18 years. The sample was constructed by students of primary and lower secondary schools of Prishtina region. School population regarding the gender composition was $38.8 \%$ boys and $61.2 \%$ girls. $85.4 \%$ of samples come from urban areas and $14.6 \%$ from rural areas.Regarding to academic achievement students are classified as follows:exellent,very good,good,enough,not enough.In Kosovo in pre-University education grades are from one five.The classification is done based on the average mark of self-reported by students in the end of research.

\subsection{Instruments}

To measure anxiety and depresion are used: Revised Children Manifest Anxiety Scale (RCMAS) and Depression SelfRating Scale for Children. These two questionaires are transalated in Albanian language by Martin Asshauer, Merita Osmani \& Ziberi.

Revised Children Manifest Anxiety Scale (RCMAS) is a 28-item self-report inventory used to measure anxiety in children, for clinical purposes (diagnosis and treatment evaluation), educational settings, and for research purposes. The RCMAS consists of 28 Anxiety items and was developed by Reynolds and Richmond (1978) to assess "the degree and quality of anxiety experienced by children and adolescents" (Gerald and Reynolds, 1999, p. 323). Wisniewski, Mulick, Genshaft and Coury (1987) examined the test-retest reliabilities of the RCMAS with 161 children in Grades 6 to 8. Analyses of retesting after one and five weeks indicated "good reliability" (Pearson correlations from .60 to .88, significant at $p<.01, p .67$ ) and an insignificant difference between test and retest mean raw scores. These results would support the stability of the scale over brief periods. With retesting after a substantial longer period, nine months, Reynolds (1981) found a .68 correlation between RCMAS Anxiety Scale scores for 534 children in Grades 4 to 6 . This would be indicative of relatively high temporal stability. The RCMAS is suitable for individual or group administration, by clinicians, researchers or teachers, with 6 to 19 year old children. Each item is given a score of one for a "yes" response, yielding a Total Anxiety score. A score above 18 has been suggested as indicative of possible depressive disorder. In this study the reliability of the scale was assessed using Cronbach alpha coefficients. Cronbach's alphas for the 28 items of Depression Self-Rating Scale for Children were .84. Thus showed that has good internal consistency.

The Depression Self-Rating Scale for Children was developed in 1978 as part of a Masters of Philosophy Thesis at the University of Edinburgh. The Depression Self Rating Scale (DSRS) is an 18-item self-report measure for children (Denda, Kako, Kitagawa, \& Koyama, 2006), which has been used in a range of cross-cultural contexts (Denda, Kako, Kitagawa, \& Koyama, 2006). This instrument records symptoms over the past week. Items are presented as statements, e.g. "I sleep very well." Responses are a 0 'mostly', 1 'sometimes', 2 'never'. Scores are then added. A score above 15 has been 
suggested as indicative of possible depressive disorder. Author reported test-retest reliability coefficient of 0.80 and a split-half reliability of 0.86 (Birleson, 1981). Further studies have found split-half reliabilities ranging from 0.61-0.85 and alpha coefficients ranging from $0.73-0.90$ (Birleson, 1981). This measure has moderate concurrent validity and demonstrated discriminative validity with acceptable sensitivity and specificity (Birleson, 1981). In this study the reliability of the scale was assessed using Cronbach alpha coefficients. Cronbach's alphas for the 18 items of Depression SelfRating Scale for Children were .75. Thus showed that has good internal consistency.

Students' GPA was accepted as the indicator of their academic success.

\section{2 .Data Analysis}

The data analysis was performed using SPSS 21.0 software package and Microsoft Excel 2007. Since the scores obtained by study group from the scales don't show a normal distribution, non- arametric tests were used. Thus, MannWhitney $U$ test was used to analyze whether student's anxiety, depression and academic succes levels differ significantly according to tenderand residence. Kruskal- Wallis $\mathrm{H}$ test was used to analyze whether student's anxiety, depression and academic succes levels differ significantly according to their age-group and to analyze whether academic succes levels differ significantly according to their anxiety and depression levels. The multiple standard regresion analize is used to etamine predictive poker of anxiety, depresion, age, gender and residence in the academic succes levels. The results obtained from analysis are summarized in the finding section.

\section{Results}

\subsection{Anxiety and depression}

Results showed that 15,7 of cases resulted with anxiety; by sex $3,4 \%$ are boys and $12,4 \%$ are girls. With depression are $22 \%$ of sample; by sex $4,7 \%$ are boys and 17,4 are girls.

Based on found correlations we have some statistically important differences in anxiety and depression level by gender, age and location. Gender is in significant positive correlation with anxiety $(r=.24, p<.00)$, which means girls have correlation with highest levels of anxiety and in this case the effect size is small. (Tab.1). Also in case of depression gender is in positive significant correlation with highest levels of depression $(r=.20, p<.00)$, where girls have correlation with highest levels of depression and in this case the effect size is small. (Tab.1).

Chi-square test (me Yates Continuity Correction) indicates that we have significant association between gender and depression presence, $X 2(1, n=163)=7.028, p=.008$, phi $=.22$. This has a small effect size.From this analysis we understand that in cases with depression $81.8 \%$ are girls and $12.8 \%$ boys. We don't have significant association between gender and anxiety presence. Also, we don't have significant association between residence and anxiety $I$ depression presence.

We calculated the Eta to estimate association between age and depression presence; in this case Eta=.022 and in case of anxiety eta $=016$. This is a small effect size in both cases.

It is used Man-Whitney technique for testing differences between groups within variables by sex.Therefore MannWhitney test has found that there are statistically important differences between girls ( $M d=11 ; N=98$ ) and boys ( $M d=10$; $\mathrm{N}=65$ ) in depression level; $\mathrm{U}=2601.500, \mathrm{Z}=-2.841, \mathrm{p}<.04, \mathrm{r}=.21$ (this is a moderate effect size). With this technique there are not found differences in anxiety level.Also there are not found differences in case of location.

Table 1. Intercorelations, Means and Standard Deviations for variables ( $N=132)$

\begin{tabular}{|l|l|l|l|l|l|l|l|l|}
\hline Correlations & Sex & Residence & Age & Success & ANXIETY & DEPRESSION & Mean & SD \\
\hline \\
0 \\
0 \\
0 \\
0
\end{tabular}




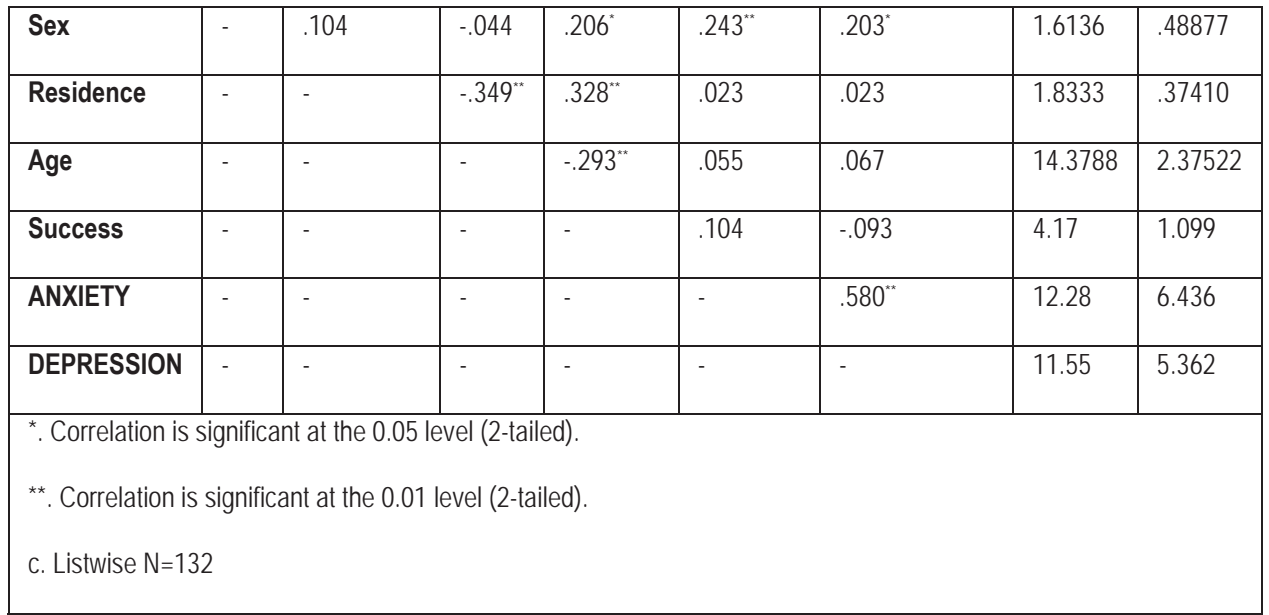

\subsection{Success at school}

In terms of academic achievement, students are classified as follows: exellent were - $58.8 \%$; very good-15.5\%; good$19.6 \%$; enough - $4.1 \%$ not enough - $2.1 \%$.

Gender is in significant positive correlation with success in school $(r=.20, p<.01)$,where girls have correlation with highest levels of success (Tab.1).In this case the effect size is small.Residence is in positive significant correlation with success in school $(r=.32, p<.01)$, where students from city have correlation with highest levels of success(Tab.1).In this case the effect size is medium.Age is in negative significant correlation with success in school $(r=-.20, p<.01)$ where younger ages have correlation with highest levels of success Tab.1.In this case the effect size is small.

To investigate the report between success and gender we have used Kendall-Tau analysis. It indicates that we do not have significant association between them. $(161)=.314, p<.00$. But Kendall Tau analysis has found positive significant association between success and residence. This means that students from urban areas had better success. This is a medium effect size.

\subsection{Anxiety,depression and success at school}

Results showed that anxiety and depression don't have significant correlation with school success but have positive significant correlation between each other with big effect size $(r=.58, p<.00)$ (Tab.1). Non significantly the high level of depression was in correlation with lowest success. In case of anxiety we have positive non-significant correlation where the highest level of anxiety resulted with the highest level of success.

The multiple regression analysis with academic achievement as a depended variable and gender, residence, age, anxiety and depression as independent variables resulted in a model with statisticall significance $(R 2=.216, F(5,131)=6.598$, $p<.00)$ (Tab.2). Hovewer, the model describes only $21 \%$ of shown success variance, where significant unique contribution have given gender $(\beta=.17, p<.04)$, residence $(\beta=.24, p<.00)$, age $(\beta=-.19, p<.02)$ depression $(\beta=-.24, p<.01)$ and anxiety $(\beta=.20, p<.03)$. (Tab.3). 
Table 2. Arithmetic average, standard deviation and correlations between succes at school and gender, residence, age, anxiety, depression

\begin{tabular}{|c|c|c|c|c|c|c|c|}
\hline Variablat & M & SD & Sex & Residence & Age & Anxiety & Depression \\
\hline School Success (GPA) & 4.17 & 1.099 & .206 & .328 & -.293 & .104 & -.093 \\
\hline \multicolumn{8}{|l|}{ Predictor variables } \\
\hline Sex & 1.6136 & .48877 & - & .104 & -.044 & .243 & .203 \\
\hline Residence & 1.8333 & .37410 & - & - & -.349 & .023 & .023 \\
\hline Age & 14.3788 & 2.37522 & - & - & - & .055 & .067 \\
\hline Anxiety & 12.28 & 6.436 & & & & - & .580 \\
\hline Depression & 11.55 & 5.362 & & & & & - \\
\hline
\end{tabular}

Table 3. Summary of standard regression analysis gender, residence, age, anxiety and depression while predicting success at school

\begin{tabular}{|l|l|l|l|}
\hline Variables & $\boldsymbol{B}$ & SEB & $\beta$ \\
\hline Sex & .383 & .184 & .170 \\
\hline Residence & .712 & .249 & .242 \\
\hline Age & -.091 & .039 & -.197 \\
\hline Anxiety & .036 & .017 & .208 \\
\hline Depression & -.049 & .020 & -.241 \\
\hline Constant & 3.865 & & \\
\hline Note: $\mathrm{R}^{2}=.216, \mathrm{~F}(5,131)=6.598, \mathrm{p}<.00$ \\
\hline
\end{tabular}

So Kruskal Wallis test found that there are not any statisticall differences between the groups by success in school.

Kruskal-Wallis analysis performed on groups by school success showed that there are not any significant differences in depression level between groups (not enough succes, $n=4$ : enough success, $n=8$ good success, $n=31$ : very good success, $n=28$ : and $n=103$ excelent success ) $X 2(4, n=174)=7.996, p=.092$. Cases with bad success had the highest median ( $M d=15.5)$ comparing to other groups $(M d=10.5),(M d=11),(M d=12)$ dhe $(M d=10)$.

Kruskal -Wallis analysis performed on groups by success in schoolshowed that there are not any significant differences on anxiety levels (not enough success, $n=4$ : enough success, $n=8$ : good success, $n=36$ : very good success, $n=27$ : and exellent success, $n=101) \times 2(4, n=176)=5.227, p=.265$. Cases with good success had highest median $(M d=14)$, comparing to other groups $(M d=13),(M d=13),(M d=9)$ dhe $(M d=8)$. Overall, groups with higher success had higher level of anxiety. 


\section{Limitations}

A limitation is the measure of academic success based in only student's self-report average of their marks. However, it should be noted that there it is a empiric evidence(meta-analysis ) which suggests that self-report of marks's average reflects good actual performance (Kuncel et al., 2005). In fact Chi-square test showed that academic achievement of study are statistically higher than official reported marks in years 2004-2005 in Kosova's level X2 $(4, n=219)=32.029$, p<.00 (MASHT,2008).

\section{Discussions and conclusions}

Finding of a higher level of depression than anxiety are interesting; but however as prevelance are in range of findings from different known researches (Bernstein \& Borchardt, 1991; Boyd, Kostanski, Gullone, Ollendick \& Shek, 2000; Hammen \& Rudolph, 2003); in the other side their presence in our case with big effect size is something accepted in research literature (Costello, Mustillo, Erkanli, Keeler \& Angold, 2003).

Findings that these disorders are often present in girls (Rutter, et al., 2008, Costello, Mustillo, Erkanli,Keeler \& Angold, 2003 ) based in correlations they are verified only for depression and not for anxiety with assocciation and difference between groups statistical analysis.

Findings of higher of depression than the anxiety are interesting but however as a prevelance are in a range (Strahan, 2003) to most of the research findings, but in some cases contrary to most of the research findings, Preiss and Franova (2006) found no effect of gender on academic achievement of school students.

Findings that anxiety and depression have no significant correlations with success in school despite that students who had more anxiety and those who had less depression had better results in school, they hadn't achieved statistical significance in comparative and differences between groups analysis;thus showed that relationship between academic performance and anxiety /depression symptomatology is complex; and as Ormord (2000) stated "anxiety and academic achievements has been a difficult relationship to clearly elucidate". This goes in line with findings of one longitudinal study in community (Reinherz, Giaconia, Pakiz, Silverman, Frost, \& Lefkowitz, 1993). Overall all tha variables as gender, age, residence, anxiety and depression each gave predictive power of success.

Despite of these findings we are sure that understanding the relationship between psychopathology and academic performance may have implications for devising counselling interventions directed at the negative effects of psychological distress on students' learning outcomes.

\section{References}

Asarnow, J. R., Jaycox, L. H., Duan, N, LaBorde, A. P., Rea, M. M., Tang, L., Anderson, M., Murray, P., Landon, C., Tang, B., Huizar, D. P., \& Wells, K. B. (2005). Depression and role impairment among adolescents in primary care clinics. Journal of Adolescent Health, 37,477-483.

Bernstein, G. A. \& Borchardt, C. M. (1991). Anxiety disorders of childhood and adolescence: A critical review. Journal of the American Academy of Child and Adolescent Psychiatry, 30, 519-532.

Boyd, C. P., Kostanski, M., Gullone, E., Ollendick, T. H. \& Shek, D. T. L. (2000). Prevalence of anxiety and depression in Australian adolescents: Comparisons with worldwide data. The Journal of Genetic Psychology 161, 479-492.

Costello, E. J., Mustillo, S., Erkanli, A., Keeler, G. \& Angold, A. (2003). Prevalence and development of psychiatric disorders in childhood and adolescence. Arch Gen Psychiatry, 60, 837-844.

Crystal, D. S., Chen, C., Fuligni, A. J., Stevenson, H.W., Hsu, C., Ko, H., Kitamura, S., \& Kimura, S. (1994). Psychological maladjustment and academic achievement: a cross-cultural study of Japanese, Chinese, and American high school students. Child Development. 65 (3): 738 - 753.

Denda, K., Kako, Y., Kitagawa, N., \& Koyama, T. (2006). Assessment of depressive symptoms in Japanese school children and adolescents using the Birleson Depression Self-Rating Scale. International Journal of Psychiatry in Medicine, 36(2):231-241. 
Deroma, V., Leach, J., Leverett, J., Patrick, J. (2009). The Relationship Between Depression and College Academic Performance. College Student Journal: 43: $325-334$.

Edwards, M.J., Holden, R.R. (2001). Coping, meaning in life, and suicidal manifestations: Examining gender differences. J. Clin. Psychol., 59:1133-1150.

Eisenberg, D., Golberstein, E., Hunt, J. (2009). Mental Health and Academic Success in College. B.E. Journal of Economic Analysis \& Policy, 9(1): Article 40.

Essau, C. A., Conradt, J., Petermann, F. (2000). Frequency, comorbidity and psychosocial impairment of anxiety disorders in German adolescents. Journal of Anxiety Disorders, 14, 263-279.

Fernández-Castillo, A. \& Gutiérrez-Rojas, M.E. (2009). Selective attention, anxiety, depressive symptomatology and academic performance in adolescents. Electronic Journal of Research in Educational Psychology. Número 17 Vol.7 (1),

Fine, J. M. \& Carlson, C. (1994). A systems-ecological perspective on home-school intervention.In Fine, J.M. \& Carlson, C. (Eds). The Handbook of Family-school Intervention: A System Perspective, Massachusetts: Allyn and Bacon.

Gerard, A.B.; \& Reynolds, C.R. (1999) .Characteristics and applications of the Revised Children's Manifest Anxiety Scale., in Maruish, M.E. (ed.) The use of psychological testing for treatment and planning and outcomes assessment (2nd edition, Mahwah, Lawrence Erlbaum Associates), pp. 323-340.

Hammen, C. \& Rudolph, K. D. (2003). Childhood mood disorders. In E. J. Mash \& R. A. Barkley (Eds.), Childhood psychopathology (pp. 233-278) New York: Guilford.

Herrera, A. \& Maldonado, A. (2002). Depresión, cognición y fracaso académico. [Depression, cognition and academic failure.] Revista Internacional de Psicología Clínica y de la Salud, 2(1), 25-50.

Hughes, A. A., Lourea- Waddell, B. \& Kendall, P. C. (2008). Somatic complaintsin children with anxiety disorders and their unique prediction of poorer academic performance. Child Psychiatry Hum Dev, 39, 211-220.

lalongo N, Edelsohn G, Werthamer-Larsson L, Crocket L, Kellam S (1994) The significance of selfreported anxious symptoms in first grade children. J Abnorm Child Psychol 22:441-455

lalongo N, Edelsohn G, Werthamer-Larsson L, Crocket L, Kellam S (1995) The significance of selfreported anxious symptoms of first grade children: prediction to anxious symptoms and adaptive functioning in fifth grade. J Child Psychol Psychiatr 36:427-427

Ialongo, N., Edlesohn, G., Werthamer-Larsson, L., Crockett, L., \& Kellam, S. (1995). The significance of self-reported anxious symptoms in first grade children: Prediction to anxious symptoms and adaptive functioning in fifth grade. Journal of Child Psychology and Psychiatry, 3, 427-437. doi:10.1111/j.1469-7610.1995.tb01300.x

Kessler, R.C., Foster, M.P.H., Saunders, W.B., Stang, P.E. (1995) Social consequences of psychiatric disorders I : educational attainment. Am J Psychiatr 152:1026-1032

Kuncel, N. R., Credé, M., \& Thomas, L. L. (2005). The validity of self-reported grade point averages, class ranks, and test scores: A meta-analysis and review of the literature.Review of Educational Research, 75,63-82.

Kusche, C.A., Cook, E.T. \& Greenberg, M.T. (1993) Neuropsychological and cognitive functioning in children with anxiety, externalizing, and comorbid psychopathology. J Clin Child Psychol 22:172-195

Locke, B. D. (2009). Center for the Study of Collegiate Mental Health (CSCMH), 2009 Pilot Study: Executive Summary [on-line]. Available: http://www.sa.psu.edu/caps/pdf/2009-CSCMH-Pilot-Report.pdf

Ministria e Arsimit, Shkencës dhe e Teknologjisë e Kosovës,MASHT. (2008). Treguesit dhe të dhënat statistikore në arsim, 2004/05, 05/06, 06/07; f.18

Mazzone, L., Ducci, F., Scoto, M. C., Passaniti, E., D'Arrigo, V. G. \& Vitiello, B. (2007). The role of anxiety symptoms in school performance in a community sample of children and adolescents. BMC Public Health, 7,347.

Muris P, Meesters C. (2002). Symptoms of anxiety disorders and teacher-reported school functioning of normal children. Psychological Reports 91(2):588-590.

Nolen-Hoeksema, S. (2000). The role of rumination in depressive disorders and mixed anxiety/depressive symptoms. Journal of Abnormal Psychology, 109(3), 504-511, doi:10.1037//0021-843X.109.3.504.

Ormord, J. E. (2001). Educational psychology. New Jersy: Errill and Imprint of Prentice Hall Upper Saddle River.

Owayed, E. F. (2005). Academic achievement and its relationship with anxiety, selfesteem, optimism, and pessimism in Kuwaiti students. Social Behavior and Personality. .Retrieved April 30, 2008, from http://findarticles.com/p/articles/mi_qa3852/is_200501?pnum=8\&opg=n9520814

Owens, M., Stevenson, J., Hadwin, J. A., \& Norgate, R. (2012). Anxiety and depression in academic performance: An exploration of the mediating factors of worry and working memory. School Psychology International, 33, 433449.doi:10.1177/0143034311427433 
Pine, D. S., Wasserman, G. A. \& Workman, S. B.(1999). Memory and anxiety in prepubertal boys at risk for delinquency. Journal of the American Academy of Child Adolescent Psychiatry, 38, 1024-1031.

Preiss, M., \& Franova, L. (2006). Depressive symptoms, academic achievement, and intelligence .Retrieved January 29, 2007, from STUDhttp://www.psychologia.sav.sk/sp/2006/sp1-06.htmIA PSYCHOLOGICA

Puig-Antich, J., Kaufman, J., Ryan, N. D.,Williamson, D. E., Dahl, R. E., Lukens, E.,et al. (1993). The psychosocial functioning and family environment of depressed adolescents. Journal of the American Academy of Child and Adolescent Psychiatry, 32, $244-253$.

Rains, D. (2004). Principios de neuropsicología humana. [Principles of human neuropsychology.] México: McGraw-Hill.

Reinherz, H. Z., Giaconia, R. M., Pakiz, B., Silverman,A. B., Frost,A. K., \& Lefkowitz,E. S. (1993). Psychosocial risks for major depression in late adolescence: A longitudinal community study. Journal of the American Academy of Child and Adolescent Psychiatry, 32,1155-1163.

Reynolds, C. \& Richmond, B. (1978). What I think and feel: A revised measure of children's manifest anxiety. Journal of Abnormal Child Psychology, 6, 271-280.

Rutter, M., Bishop, D. V., Pine, S., Scott, S., Stevenson, J., \& Taylor, T. E. ( 2008). Rutter's Child and Adolescent Psychiatry, 5 th Edition. Blackwell Publishing Limited.

Spielberger, C. D. (2006). Cross-cultural assessment of emotional states and personalit traits. European Psychologist, 11(4), 297-303, doi: 10.1027/1016-9040.11.4.297.

Strahan, E.Y. (2003). The effects of social anxiety and social skills on academic performance. Personality and Individual Differences, $34(2), 347-366$.

Tobias, S. (1979). Anxiety research in educational psychology. Journal of Education Psychology, 71. 573-582.

Von Ameringen M, Mancini C, Farvolden P (2003) The impact of anxiety disorders on educational achievement. J Anxiety Disord 17:561-571

Von Ameringen, M., Mancini, C. \& Farvolden P.(2003). The impact of anxiety disorders on educational achievement. Journal of Anxiety Disorders, 17, 561-571

Wisniewski, J.J.; Jack, J.; Mulick, J.A.; Genshaft, J.L.; and Coury, D.L. (1987) "Test-Retest reliability of the Revised Children's Manifest Anxiety Scale",Perceptual and Motor Skills, vol. 65(1), pp.67-70.

Wood, J. ( 2006). Effect of Anxiety Reduction on Children's School Performance and Social Adjustment. Developmental Psychology, 42(2), 345-349.

Yousefi F, Talib M A, Mansor B M, Juhari B R and Redzuan R(2010) Test Anxiety and Academic Achievement among Iranain Adolescents. Journal of asian social Science. Vol 6(5).

Zaid, Z. A., Chan, S. C., \& Ho, J. J. (2007). Emotional disorders among medical students in a Malaysian private medical school. Singapore Medical Journal 48 (10): 895 - 899. 